\title{
Teaching Video NeuroImages: Wall Enhancement With Slow Blood Flow and Thrombosis Prior to Basilar Aneurysm Rupture
}

Fei Peng, MS, * Miaoqi Zhang, BE, * Hao Niu, MS, * Xin Feng, MD, Xin Tong, MS, Baorui Zhang, MD, Fei Yuan, MD, Chun Yuan, PhD, Rui Li, PhD, † and Aihua Liu, MD†

Neurology ${ }^{\circledR}$ 2021;96:e962-e963. doi:10.1212/WNL.0000000000010820

Figure Axial High-Resolution MRI (HR-MRI) and Streamline of 4D-flow MRI

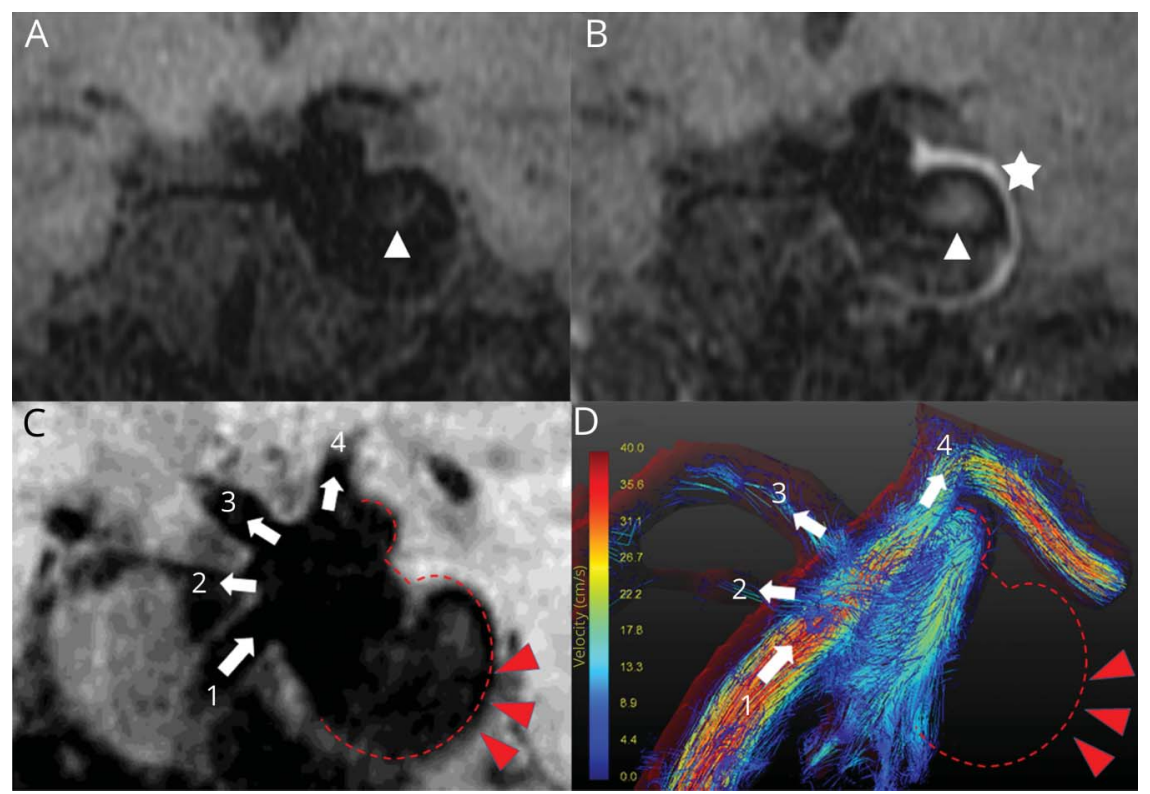

Precontrast (A) and postcontrast (B) HR-MRI revealed thrombosis (triangle) and aneurysmal wall enhancement (star). PD-VISTA (C) and streamline (D) demonstrated slow flow in aneurysm (arrowheads) and flow direction (white arrows), from basilar artery (1) to the aneurysm, right superior cerebellar artery (2), right (3) and left (4) posterior cerebral artery.

A 31-year-old man presented with basilar aneurysm noted on high-resolution MRI (HR-MRI), which showed thrombosis and aneurysmal wall enhancement (figure, A and B). 4D-flow MRI revealed a vortex near the aneurysm ostium and slow flow in the aneurysm, which may suggest low rupture risk (video and figure, $\mathrm{C}$ and $\mathrm{D}$ ). However, the aneurysm ruptured after 1 month of conservative treatment. Hemodynamics are important to aneurysm formation and rupture. ${ }^{1}$ In the aneurysm prerupture state, slow flow and thrombosis may promote inflammation, demonstrated as aneurysmal wall enhancement, and expedite aneurysm rupture. ${ }^{2}$ HR-MRI and

\section{Correspondence}

Dr. Liu

liuaihuadoctor@163.com

or Dr. Li

leerui@tsinghua.edu.cn

\section{MORE ONLINE}

\section{- Video}

\section{$\rightarrow$ Teaching slides}

links.lww.com/WNL/

B235

*These authors contributed equally to this work.

tThese corresponding authors contributed equally to this work.

From the Department of Interventional Neuroradiology (F.P., H.N., X.T., B.Z., F.Y., A.L.), Beijing Neurosurgical Institute, Capital Medical University; Department of Biomedical Engineering (M.Z., R.L.), Center for Biomedical Imaging Research, Tsinghua University; Department of Neurosurgery (X.F.), Beijing Hospital, National Center of Gerontology; Graduate School of Peking Union Medical College (X.F.), Beijing, China; and Department of Radiology (C.Y.), University of Washington, Seattle.

Go to Neurology.org/N for full disclosures. Funding information and disclosures deemed relevant by the authors, if any, are provided at the end of the article. 
4D-flow MRI could be combined to identify dangerous aneurysms that mandate prompt intervention.

\section{Study Funding}

This work was supported by the Natural Science Foundation of China (81771233 and 81901197), the Natural Science Foundation of Beijing, China (7142032), the Specific Research Projects for Capital Health Development (2018-22041), Beijing Science and Technology Planning Project (Z181100009618035), and Beijing Municipal Administration of Hospitals' Ascent Plan (DFL20190501).

\section{Disclosure}

The authors report no disclosures relevant to the manuscript. Go to Neurology.org/N for full disclosures.

\begin{tabular}{|c|c|c|}
\hline \multicolumn{3}{|c|}{ Appendix Authors } \\
\hline Name & Location & Contribution \\
\hline $\begin{array}{l}\text { Fei Peng, } \\
\text { MS }\end{array}$ & $\begin{array}{l}\text { Capital Medical } \\
\text { University, Beijing }\end{array}$ & Study concept and design \\
\hline $\begin{array}{l}\text { Miaoqi } \\
\text { Zhang, } \\
\text { BE }\end{array}$ & $\begin{array}{l}\text { Tsinghua } \\
\text { University, Beijing }\end{array}$ & Acquisition and interpretation of data \\
\hline $\begin{array}{l}\text { Hao Niu, } \\
\text { MS }\end{array}$ & $\begin{array}{l}\text { Capital Medical } \\
\text { University, Beijing }\end{array}$ & Acquisition and interpretation of data \\
\hline
\end{tabular}

Appendix (continued)

\begin{tabular}{|c|c|c|}
\hline Name & Location & Contribution \\
\hline $\begin{array}{l}\text { Xin Feng, } \\
\text { MS }\end{array}$ & $\begin{array}{l}\text { Peking Union } \\
\text { Medical College, } \\
\text { Beijing }\end{array}$ & Analysis and interpretation of data \\
\hline $\begin{array}{l}\text { Xin Tong, } \\
\text { MS }\end{array}$ & $\begin{array}{l}\text { Capital Medical } \\
\text { University, Beijing }\end{array}$ & Analysis and interpretation of data \\
\hline $\begin{array}{l}\text { Baorui } \\
\text { Zhang, } \\
\text { MD }\end{array}$ & $\begin{array}{l}\text { Capital Medical } \\
\text { University, Beijing }\end{array}$ & Analysis and interpretation of data \\
\hline $\begin{array}{l}\text { Fei Yuan, } \\
\text { MD }\end{array}$ & $\begin{array}{l}\text { Capital Medical } \\
\text { University, Beijing }\end{array}$ & Analysis and interpretation of data \\
\hline $\begin{array}{l}\text { Chun } \\
\text { Yuan, } \\
\text { PhD }\end{array}$ & $\begin{array}{l}\text { University of } \\
\text { Washington, } \\
\text { Washington }\end{array}$ & $\begin{array}{l}\text { Technical guidance and study } \\
\text { supervision }\end{array}$ \\
\hline $\begin{array}{l}\text { Rui Li, } \\
\text { PhD }\end{array}$ & $\begin{array}{l}\text { Tsinghua } \\
\text { University, Beijing }\end{array}$ & $\begin{array}{l}\text { Critical revision of manuscript for } \\
\text { intellectual content, study supervision }\end{array}$ \\
\hline $\begin{array}{l}\text { Aihua } \\
\text { Liu, MD }\end{array}$ & $\begin{array}{l}\text { Capital Medical } \\
\text { University, Beijing }\end{array}$ & $\begin{array}{l}\text { Critical revision of manuscript for } \\
\text { intellectual content, study } \\
\text { supervision }\end{array}$ \\
\hline
\end{tabular}

\section{References}

1. Khan MO, Arana VT, Rubbert C, et al. Association between aneurysm hemodynamics and wall enhancement on 3D vessel wall MRI. J Neurosurg Epub 2020 Jan 10.

2. Turjman AS, Turjman F, Edelman ER, Role of fluid dynamics and inflammation in intracranial aneurysm formation. Circulation 2014;129:373-382. 


\section{Neurology}

\section{Teaching Video NeuroImages: Wall Enhancement With Slow Blood Flow and Thrombosis Prior to Basilar Aneurysm Rupture \\ Fei Peng, Miaoqi Zhang, Hao Niu, et al.}

Neurology 2021;96;e962-e963 Published Online before print September 11, 2020

DOI 10.1212/WNL.0000000000010820

This information is current as of September 11, 2020

\section{Updated Information \&} Services

References

Subspecialty Collections

Permissions \& Licensing

Reprints including high resolution figures, can be found at: http://n.neurology.org/content/96/6/e962.full

This article cites 1 articles, 1 of which you can access for free at: http://n.neurology.org/content/96/6/e962.full\#ref-list-1

This article, along with others on similar topics, appears in the following collection(s):

\section{All Cerebrovascular disease/Stroke}

http://n.neurology.org/cgi/collection/all_cerebrovascular_disease_strok e

MRI

http://n.neurology.org/cgi/collection/mri

Subarachnoid hemorrhage

http://n.neurology.org/cgi/collection/subarachnoid_hemorrhage

Information about reproducing this article in parts (figures,tables) or in its entirety can be found online at:

http://www.neurology.org/about/about_the_journal\#permissions

Information about ordering reprints can be found online:

http://n.neurology.org/subscribers/advertise

Neurology ${ }^{\circledR}$ is the official journal of the American Academy of Neurology. Published continuously since 1951, it is now a weekly with 48 issues per year. Copyright (C 2021 American Academy of Neurology. All rights reserved. Print ISSN: 0028-3878. Online ISSN: 1526-632X.

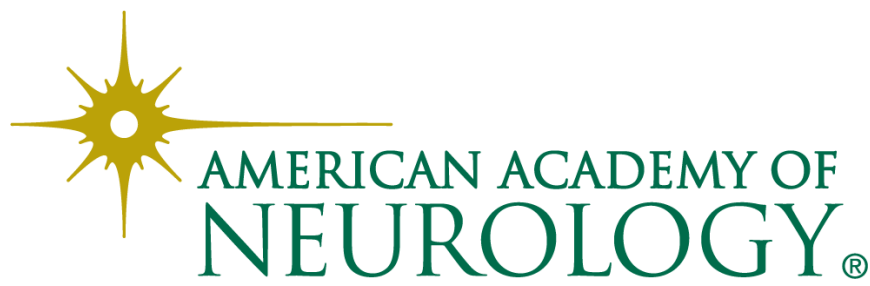

